УДК 376-056.26(4)

DOI: 10.37026/2520-6427-2019-99-3-99-102
Лариса ЯЦЕНЮК,

старша викладачка кафедри педагогіки, психології та корекиійної освіти Рівненського ОІППО
Рада КОЗАК,

методистка ресурсного ичентру

підтримки інклюзивної освіти Рівненського ОІППО

\title{
УПРОВАДЖЕННЯ ІНКЛЮЗИВНОЇ ОСВІТИ: ДОСВІД ЗАРУБІЖЖЯ
}

У статті окреслено особливості впровадження інклюзивної освіти за кордоном. Здійснено аналіз нормативно-правової бази інклюзивної освіти. Представлено різноманітні моделі інклюзивного навчання дітей не лиме з особливими освітніми потребами, а ŭ загального розвитку. Охарактеризовано систему підготовки педагогів до навчання дітей з особливостями психофізичного розвитку.

Ключові слова: інклюзія, інклюзивна освіта, інклюзивне навчання, діти з особливими освітніми потребами, індивідуальний навчальний план, модифікована програма, нозологї, нормативно-правова база.

B статье рассмотрены особенности внедрения инклюзивного образования за границей. Анализируется нормативно-правовая база инклюзивного образования. Представлены различные модели инклюзивного обучения детей не только с особыми образовательными потребностями, но и общего развития. Дана характеристика системе подготовки педагогов к обучению детей с особенностями психофизического развития.

Ключевые слова: инклюзия, инклюзивное образование, дети з особыми образовательными потребностями, индивидуальныии учебньій план, модифицированная программа, нозологии, нормативно-правовая база.

The article discusses the features of the introduction of inclusive education abroad. Covering the development of inclusive education abroad, the authors rely on studies by foreign scientists from around the world, analyze the regulatory framework of inclusive education, reveal different models of inclusive education for children with special educational needs and general development children, a system for training teachers to teach children with psychophysical development.

The new Law on Education of Ukraine provides for the right to choose the parents (representatives) of the child with special educational needs of the educational institution and the form of organization of the educational process.

The questions of inclusive education in the education of North American countries were studied by scientists $J$. Dey, E. James, J. James Wilson, J. Zain et al.

American scholars in special education, D. Johnson, R. Johnson, G. Wiggins, proposed to include children with special needs in general education institutions. Similar ideas have become an impetus for the development of inclusive education.
In our opinion, Canada's experience is important for us in terms of ensuring equal access to quality education. Canadian scholars have found that the educational achievement of pupils with special educational needs attending special classes and pupils in mass schools, while providing appropriate support, varies slightly, but successes in socialization and adaptation in the former are much higher.

Under the "Law on education" children with the features ofdevelopment must study together with healthy children inestablishment of education, territorial close to the residencetheir, and to get professional support from the side ofteachers specialist.

Key words: inclusion, inclusive education, children with special educational needs, individual curriculum, modified curriculum, nosoology, regulatory framework.

Інклюзивна освіта - важлива складова соціальної політики України, система освітніх послуг, що грунтується на принципі забезпечення основного права дітей на освіту та права здобувати іiї за місцем проживання, що передбачає навчання дитини з особливими освітніми потребами в умовах загальноосвітнього закладу. В основу інклюзивної освіти покладена ідеологія, яка виключає будь-яку дискримінацію дітей, яка забезпечує однакове ставлення до всіх людей, але створює спеціальні умови для дітей з особливими потребами.

Актуальність статті полягає у висвітленні досвіду системи інклюзивної освіти за кордоном та часткового запровадження його у вітчизняних закладах освіти. Соціально-економічні процеси, що відбуваються сьогодні в Україні, актуалізують необхідність вивчення досвіду інклюзивної освіти за кордоном як позитивної тенденції освітнього простору [3].

Мета статті - охарактеризувати особливості системи інклюзивної освіти в зарубіжних країнах, зокрема Австрії, Бельгії, Італії, Канаді, Німеччині, Польщі, США, Швеції, порівняти їх з організацією такого навчання в Україні.

Виклад основного матеріалу. Новим Законом України «Про освіту» (2017) передбачено право вибору батьками (представниками) дитини 3 особливими освітніми потребами закладу освіти та форм організації освітнього процесу. Упровадження інклюзивної освіти також є важливим чинником реалізації Концепції «Нова українська школа».

За даними МОН України, на сьогодні кожна шоста школа в нашій державі вже є інклюзивною. 
Вагомі здобутки в питаннях організації, науково-методичного супроводу, інклюзивного навчання має і Рівненщина. Так, станом на жовтень 2018 року інклюзивним навчанням було охоплено 225 шкіл, що на 50 більше, ніж у квітні 2018 р., а також функціонувало 462 інклюзивних класи, в яких навчалося 582 дитини 3 особливими освітніми потребами. Для супроводу дітей уведено 378,5 посад асистентів-учителів, що на 115 штатних одиниць більше ніж у квітні 2015 року.

Як відомо, впровадження інклюзивної освіти в Україні почалося порівняно недавно, тоді як у передових зарубіжних країнах перебудова спеціальної освіти розпочалася ще у 70-х роках минулого століття. Зокрема, інтегроване та інклюзивне навчання дітей $з$ особливостями розвитку було визначено основною формою здобуття освіти. Проаналізуємо докладніше досвід цих країн.

Питання інклюзивного навчання в освіті північно-американських країн досліджували науковці Дж. Дей, Е. Джеймс, Ю. Джеймс-Вілсон, Дж. Зайн та ін. [4]. Зокрема, американські вчені в галузі спеціальної освіти Д. Джонсон, Р. Джонсон, Г. Віггінс запропонували включати дітей $з$ особливими потребами у загальноосвітні заклади, що й стало поштовхом для розвитку інклюзивної освіти [1]. При цьому канадські дослідники П. Реншоу, С. Ашер, Дж. Ендрюс, Дж. Лупарт підгрунтя інклюзивної освіти вбачають у спільному навчанні дітей з особливими освітніми потребами та їхніх здорових ровесників.

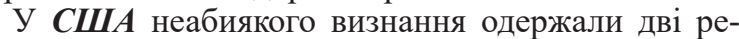
форми. Периа реформа - «Усnіх в усіх школах» розроблена Робертом Слевіном, грунтується на двох основних принципах: превентивні заходи й інтенсивне доручення дітей х особливими потребами, у середовище загальноосвітньої школи, починаючи із початкових класів. При цьому всі основні зусилля мають бути спрямовані на вирішення проблем у процесі навчання «особливих» дітей у межах звичайного класу, тобто діти з особливостями психофізичного розвитку, навчаючись у звичайному класі, інтегруються у середовище при підтримці асистента вчителя, а діти із більш важкими формами інвалідності забезпечуються персональними асистентами і педагогами із фаховою підготовкою. Друга реформа - «Проект екстернатних шкіл» - 3 моменту свого виникнення у 1986 року була реалізована у понад 1000 початкових і середніх шкіл у 41-му штаті. Її суть полягає в тому, що навчання прискорюється й розширюється, а не корегується та спрощується. Особливими рисами екстернат них шкіл є високий рівень послуг, розширений навчальний план, оптимізований процес навчання і широке залучення батьків до освітнього процесу. Система освіти для дітей з особливими освітніми потребами є різноваріантною та багатомодельною. Однією із моделей $є$ діяльність спеціальних шкіл-інтернатів, де здобувають освіту діти з порушеннями зору або незрячі діти-сироти. Крім того, слабозорі учні мають змогу навчатися і в спеціальних класах масових шкіл, отримуючи реабілітаційні послуги. Спеціальні школи-інтернати виконують функції ресурсних центрів, надаючи методичні, навчальні та реабілітаційні послуги [5].

Неабияке значення для вітчизняної освіти щодо забезпечення рівного доступу до якісної освіти має

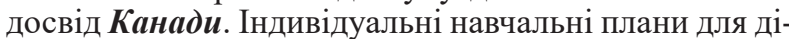
тей з особливостями розвитку почали впроваджувати у масових школах Канади наприкінці 70-х років XX століття. Зокрема, у провінціях Альберта, Манітоба,
Нова Шотландія на базі закладів освіти проводиться підготовка асистентів-учителів, а в університетах Альберти та Калгарі розробляються та впроваджуються спеціальні курси і програми для вчителів. Певна кількість канадських дітей $з$ особливими освітніми потребами навчаються в спеціальних класах та закладах. Тобто ключовою тенденцією державної політики $\epsilon$ спрямування на інклюзивне навчання. «Закон про школу» регламентує діяльність Ради з особливих проблем дітей. За поданням шкільної ради ця Рада укладає угоди як 3 установами, так і $з$ окремо взятими фахівцями, розробляє плани розвитку додаткових послуг, а також вирішує різноманітні фінансові питання.

Учні $з$ особливостями розвитку навчаються за модифікованими програмами, наприклад, для кожної дитини складається індивідуальний навчальний план, який містить інформацію про оцінювання, «сильні» та «слабкі» сторони учня, наявний рівень його знань, перехідне планування, короткий звіт у кінці року та ін. Додаткову підтримку такі діти отримують від асистента або помічника вчителя, фахівців шкільних служб або муніципальних служб супроводу. Крім того, канадські вчителі, які працюють в інклюзивних класах, отримують від держави підтримку в питаннях методичного забезпечення, участі у фахових тренінгах, освітнього асистування тощо.

Цікавим, із наукової точки зору, є дослідження I. Калініченко щодо підготовки педагогічного працівника на посаду асистента-вчителя інклюзивного класу в Канаді. Дослідник наголошує, що така підготовка передбачає ознайомлення із нормативно-правовою базою інклюзивної освіти, кваліфікаційними вимогами асистента-вчителя, особливостями реалізації індивідуальної програми розвитку, основами розуміння потреб учнів, комунікації та партнерства [2].

В освітній системі Австрії функціонують центри спеціальної освіти, фахівці яких діагностують дітей, консультують учителів, надають спеціальну методичну допомогу, проводять семінари та тренінги 3 підвищення кваліфікації, координують роботу педагогів, задіяних в інклюзивному навчанні.

Психолого-педагогічну підтримку, корекційні послуги учням з особливими освітніми потребами в школах надають спеціальні педагоги, які є штатними працівниками. Вони можуть бути асистентами вчителів, консультантами педагогів, батьків і громадськості. Тимчасову підтримку учням з особливими освітніми потребами надають фахівці із медичних і соціальних установ [2].

Особливості упровадження інклюзивної освіти Бельгії досліджували Г. Гескуере, Дж. Мурс, Г. Пудар та ін. Відповідно до Закону про освіту в цій країні створені служби психолого-медико-соціального супроводу, що допомагають у вирішенні проблеми вибору «освітнього маршруту» дитини з особливостями розвитку. Психолого-медико-соціальні центри (далі ПМС-центри) функціонують у системі масової і спеціальної освіти. Фахівці означених центрів консультують батьків, надають фахову допомогу дітям, проводять корекційно-розвиткові заняття.

У Бельгії існують різні моделі спільного навчання дітей з особливими освітніми потребами та здорових дітей, серед яких варто виокремити такі:

1) школярі з особливостями психофізичного розвитку навчаються в масових школах, а психолого-медико-соціальний супровід здійснюють спеціалісти ПМС-центрів; 
2) діти з особливими освітніми потребами відвідують уроки в масовій школі, а корекційно-розвиткові заняття - у спеціальному закладі;

3) діти із порушеннями розвитку впродовж певного періоду у навчальному році навчаються у масовій школі.

У бельгійських школах поширена практика, коли фахівців, наприклад, корекційних педагогів, для проведення індивідуальних занять із дітьми запрошують зі спеціальних закладів [5].

Чільне місце в упровадженні інклюзивного навчання серед європейських країн займає Imaлiя, де $90 \%$ дітей з особливими освітніми потребами навчаються в загальноосвітніх закладах. Саме ця країна стала однією із перших, де інклюзивне навчання було визнано найприйнятнішою формою здобуття освіти для дітей з особливими потребами.

Відповідно до «Закону про освіту» діти з особливостями розвитку мають навчатися разом зі здоровими дітьми у закладі освіти, територіально наближеному до місця їхнього проживання, та отримувати фахову підтримку з боку педагогів та різнопрофільних фахівців. Наповнюваність класу при цьому не повинна перевищувати 20 учнів (за умови, що в інклюзивному класі навчається не більше двох «особливих» дітей).

В освітніх департаментах Італії функціонують консультативні служби, співробітники яких організовують інклюзивне навчання, діагностують дітей, надають консультативну та методичну допомогу. Педагоги спільно з асистентами вчителів на кожну дитину 3 особливостями розвитку складають індивідуальні плани, враховуючи при цьому ії навчальні потреби та корекційну допомогу, що може надаватися за межами школи в центрах медико-соціальної реабілітації [5].

У Польщі інклюзивне навчання активно запроваджується 3 кінця 70-х років минулого століття як альтернатива спеціальним школам. Зокрема, інклюзивне навчання є стратегічним напрямом освітньої політики держави. Відповідно до «Закону про середню освіту» інклюзивне навчання визначено основною формою здобуття освіти дітей з особливими освітніми потребами. Учні з особливими освітніми потребами можуть відвідувати будь-яку школу за умови відповідності іiі певним критеріям (належні умови перебування в клаci, індивідуальний навчальний план, додаткові уроки тощо). Учителі, які працюють із дітьми з різними нозологіями, повинні мати спеціальну кваліфікацію [4].

Позитивним прикладом для наслідування є досвід міста Гнезно, де дитина з особливостями психофізичного розвитку вже від народження долучається до інклюзивного навчання, зокрема в місті наявні заклади дошкільної освіти, масові школи, гімназії, спеціальний шкільний осередок для дітей і молоді з особливими освітніми потребами. Спільним для всіх освітніх осередків є повна архітектурна доступність, окремі санітарні кімнати, наявність реабілітаційних та терапевтичних кімнат. Усі без винятку учні беруть активну участь у громадському житті школи. Кожна освітня установа має групу фахівців, серед яких - психолог, реабілітолог, логопед, методист. Аби працювати з такою категорією дітей, учителі повинні мати документ про наявність додаткової спеціальної освіти.

Сучасні тенденції освіти у Швеції спрямовані на розформування спеціальних шкіл та створення на їхній базі ресурсних центрів. У територіальних округах функціонують дитячі реабілітаційні центри, в яких надається допомога дітям з обмеженими можливостями.
Фахівці центрів входять до складу групи, що визначає індивідуальну освітню траєкторію дитини з особливими потребами. Крім того, підтримку сім'ям, де $\epsilon$ діти з особливостями розвитку, та освітнім закладам надає шведське Агентство спеціальної освіти, підпорядковане міністерству освіти. У Швеції кілька років тому спостерігалися суттєві структурні зміни щодо підготовки педагогів, які працюють 3 означеною категорією дітей, зокрема до програм навчання були включені модулі з корекційної педагогіки [5].

Корисним також щодо розвитку кооперативних форм організації освітньої діяльності масових і спеціальних шкіл є досвід Німеччини. Так, у країні пропонують спільне зі здоровими дітьми проведення масових заходів, окремих навчальних занять, відвідування учнями з особливими освітніми потребами масових шкіл та надання їм корекційних послуг у спеціальному закладі. Психолого-педагогічний супровід в умовах інклюзивного навчання має варіативний характер: якщо в одних школах штатним розписом передбачено посади корекційних педагогів, то в інших - спеціальні педагоги виконують функції асистента вчителя, а психолого-педагогічний супровід здійснюється педагогічними центрами. Окрім центрів, допомогу надають також медико-соціальні служби, ресурсні центри, реабілітаційні заклади [6].

Висновки. Підсумовуючи вищевикладене, 3 упевненістю можемо стверджувати, що інклюзивна освіта інтенсивно набирає обертів. На нашу думку, незважаючи на позитивний досвід розвитку інклюзивної освіти, накопичений у різних країнах світу, перед Україною стоїть чимало викликів щодо підтримки цього процесу. Зокрема, вітчизняна система освіти, зважаючи на економічні та соціальні умови й особливості менталітету, не може і не повинна сліпо наслідувати досвід зарубіжних країн. Україна стоїть на шляху створення власної системи інклюзивної освіти. При цьому варто зауважити, що досвід зарубіжних країн щодо психолого-педагогічного супроводу дітей в умовах інклюзивного навчання $є$ визначальним для системи української інклюзивної освіти і становить сьогодні неабиякий науково-практичний інтерес.

\section{СПИСОК ВИКОРИСТАНОЇ ЛТТЕРАТУРИ}

1. Бондар Т. I. Інклюзивна освіта Канади: понятійно-категорійний апарат / Т. І. Бондар // Науковий вісник Ужгородського університету. - 2017. Вип. 1 (40). - С. 27-30. - (Серія «Педагогіка. Соціальна робота»).

2. Казачінер О. С. Інклюзивна освіта в англомовних країнах / О. С. Казачінер. - Харків : Вид. група «Основа», 2018. - 79 с.

3. Колишкін О. В. Вступ до спеціальності «Корекційна освіта» : навч. посіб. / О. В. Колишкін. Суми : Університетська книга, 2013. - 392 с.

4. Колупаєва А. А. Інклюзивна освіта: реалії та перспектива : монографія / А. А. Колупаєва. - К. : Самміт-Книга, 2009. - 272 с. : іл.

5. Лапін А. В. Огляд зарубіжного досвіду інклюзивної освіти / А. В. Лапін [Електронний ресурс]. URL: file://C:/Users/User/Downloads/ooop_2013_4(1)_26\%20 (1).pdf (дата звернення: 30.05.2019).

6. Модине М. Доступ людей с ограниченными возможностями к социальным правам в Европе / М. Модине. - Страсбург, 2003. - 185 с.

Дата надходження до редакиіï: 11.06.2019 р. 